
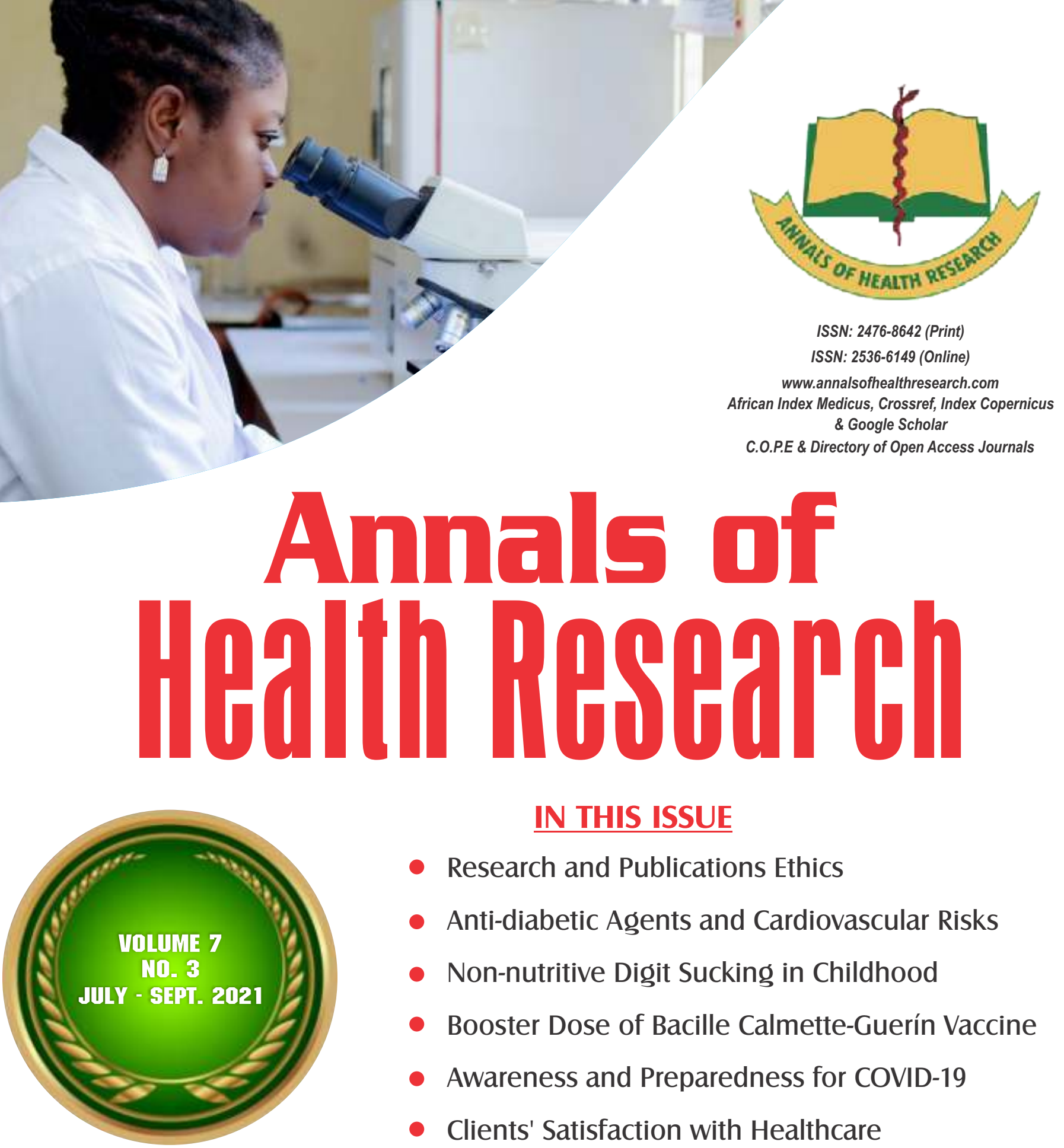

IN THIS ISSUE

- Research and Publications Ethics

- Anti-diabetic Agents and Cardiovascular Risks

- Non-nutritive Digit Sucking in Childhood

- Booster Dose of Bacille Calmette-Guerín Vaccine

- Awareness and Preparedness for COVID-19

- Clients' Satisfaction with Healthcare

- Antimicrobial Activity of Lactic Acid Bacteria

- Saddle Block for Transrectal Prostate Biopsy

- Physical and Mental Health of Stroke Survivors

- Transfusion Transmissible Infections

- Cervical Ectopic Pregnancy

PUBLISHED BY THE MEDICAL

AND DENTAL CONSULTANTS ASSOCIATION

OF NIGERIA, OOUTH, SAGAMU, NIGERIA.

www.mdcan.oouth.org.ng 


\title{
Booster Dose of Bacille Calmette-Guérin Vaccine for Tuberculosis in Low and Middle-Income Countries:
}

\section{A Systematic Review}

\author{
Oduwole OA*1, Mwankon JP2, Okebe J33, Esu EB" ${ }^{4}$, Chibuzor M5, \\ Sallahdeen A $^{6}$, Arikpo DI ${ }^{5}$, Meremikwu C5, Effa EE7, Meremikwu MM8 \\ 1 Department of Medical Laboratory Science, Achievers University, Owo, Nigeria \\ 2 Department of Family Medicine, University of Calabar Teaching Hospital, Calabar, Nigeria \\ ${ }^{3}$ Department of International Public Health, Liverpool School of Tropical Medicine, Pembroke Place Liverpool, \\ L3 5QA, UK \\ 4 Department of Public Health, College of Medical Sciences, University of Calabar, Calabar, Nigeria \\ ${ }^{5}$ Cochrane Nigeria, Institute of Tropical Diseases Research and Prevention, University of Calabar Teaching \\ Hospital, Calabar, Nigeria \\ ${ }^{6}$ Department of Vaccines and Immunity Medical Research Council Unit, at London School of Hygiene and \\ Tropical Medicine, Atlantic Boulevard Fajara, The Gambia \\ 7 Department of Internal Medicine, College of Medical Sciences, University of Calabar, Calabar, Nigeria \\ ${ }^{8}$ Department of Paediatrics, College of Medical Sciences, University of Calabar, Calabar, Nigeria
}

*Correspondence: Dr OA Oduwole, P.M.B. 1030, Owo, Nigeria. E-mail: olabisioduwole@yahoo.co.uk; olabisioduwole@achievers.edu.ng; ORCID - https://orcid.org/0000-0003-3221-1139.

\begin{abstract}
Background: The Bacille Calmette-Guérin (BCG) vaccine, given as a single dose, offers variable protection against Tuberculosis (TB). It is plausible that repeat doses could improve the effectiveness of the BCG vaccine in settings where the population remain at risk of the disease.

Objective: To assess the effectiveness of BCG revaccination as a booster dose in preventing TB in Low- and Middle- Income Countries (LMICs).

Methods: We searched the electronic databases without language or publication restrictions and followed the procedures for preparing systematic reviews, including assessing the risk of bias as outlined in the Cochrane handbook. We included randomised controlled trials (RCTs) conducted in LMICs involving children and adults receiving one or more BCG vaccine doses after the primary BCG vaccination. The incidence of severe forms of TB, active TB and adverse events were the primary outcomes.

Results: Five RCTs were included in this systematic review. Revaccination with BCG probably makes little or no difference to the risk of active TB measured after five years (Relative risk (RR) 1.16, 95\% CI 0.88 to 1.51; 348,083 participants; one study, moderate certainty evidence) or nine years post-revaccination (RR $0.96,95 \%$ CI 0.82 to 1.12; 348,083 participants; one study, moderate certainty evidence). In populations with HIV co-infection, revaccination probably increases the risk of pulmonary tuberculosis compared to placebo (RR 1.74, 95\% CI 1.00 to 3.01; 46,764 participants; one study, moderate certainty evidence). Conclusion: The available evidence suggests that BCG revaccination probably makes little or no difference in preventing tuberculosis disease in LMICs.
\end{abstract}

Key words: Bacille Calmette-Guérin, BCG, Booster dose, Revaccination, Tuberculosis, Vaccination 


\section{Introduction}

Tuberculosis (TB) remains a significant global public health problem. It is estimated that there were about 10 million cases and 2 million deaths from TB in 2018. ${ }^{[1,2]}$ Most cases and deaths occur in low- and middle-income countries (LMICs) in South-East Asia and sub-Saharan Africa, contributing $44 \%$ and $24 \%$ respectively of the global TB burden. [3] The HIV epidemic has exacerbated the burden of TB. Some regions in sub-Saharan Africa with a very high prevalence of HIV infection have reported an annual incidence of over 231 cases per $100 \quad 000$ inhabitants. [5, 6] Tuberculosis is considered a serious threat to attaining the Sustainable Development Goals and stopping TB has been linked to improvement in global development. [7]

TB is caused by the bacterium Mycobacterium tuberculosis [5], and it is acquired mainly by inhaling droplets expelled from an infected person. The spread of the infection is optimal in poorly ventilated, overcrowded living conditions. ${ }^{[8,9]}$ Not all exposure to Mycobacterium tuberculosis progress to a disease state. TB mainly affects the lungs, and clinical features develop when the body's immune system is compromised. [10,11] The emergence of HIV/AIDS has also led to more cases of TB occurring outside the lungs, known as extrapulmonary tuberculosis. ${ }^{[5]} \mathrm{A}$ diagnosis of TB is based on a positive culture from body fluids associated with clinical features. However, bacterial cultures are particularly challenging and more recent molecular tools have improved detection rates. In children, isolating the bacteria is particularly difficult due to their reduced ability to produce enough sputum. The treatment of TB involves using drug combinations for at least six months, and in situations where other structures outside the lungs are affected, the duration of treatment is longer. ${ }^{[12]}$
The risk of TB in childhood is reduced through vaccinating children at birth or within the first month of life with the Bacille Calmette-Guérin (BCG) vaccine. This vaccine is live attenuated; it stimulates a cell-mediated immune response against the organism. The vaccine mainly protects against widespread (miliary) TB infections and TB meningitis. [13]

The World Health Organisation (WHO) recommends BCG vaccination in neonates in countries with a high burden of TB and HIV. However, the level of protection from the vaccine is variable. A systematic review showed that the protection offered against TB infection was about $27 \%$ and up to $71 \%$ protection against active TB disease. [14] The protective effect of the vaccine is relatively short-lived, lasting about ten years. [15] An increase in some markers of immune activation such as interferon-gamma (IFN- $\gamma$ ) and interleukin (IL-10) have been observed in infants following revaccination. ${ }^{[16]}$ These observations suggest that a repeat or booster dose may be required to extend the period of protection; however, revaccination with BCG is currently not recommended.

The potential for revaccination or booster doses of BCG to improve the effectiveness of $\mathrm{TB}$ prevention was recently addressed at a stakeholder-driven priority-setting consultation across the West African states.[17] The meeting report identified the lack of clarity in the available evidence as the first step towards any recommendations on the subject. [17]

This systematic review summarises the existing evidence for the effect of BCG booster vaccination in preventing tuberculosis in LMICs. The review protocol was registered with the International Prospective Register of Systematic Reviews (PROSPERO). [18] 


\section{Methods}

Identification of Studies and Data Extraction

This review included randomised controlled trials (RCT) in children and adults, irrespective of location or language of publication. We searched electronic databases such as the Cochrane Central Register of Controlled Trials (CENTRAL), PubMed, the WHO International Clinical Trials Registry Platform and ClinicalTrials.gov using the following search terms: BCG, Tuberculosis, 'Mycobacterium Infections', vaccines, TB, revaccination. An initial search conducted on 20 August 2018 was updated on 16 May 2020 using the strategy that was developed (Appendix 1). We also checked the reference lists of included studies for additional studies. Two authors independently screened the search results using the pre-defined eligibility criteria as stated in the review protocol. The criteria included participants in low and middle-income countries who received one or more BCG vaccine doses after the primary BCG vaccination as recommended in the immunisation schedule. [18,19] Two authors independently extracted data while a third author resolved disagreements over eligibility or discrepancies in data extraction.

\section{Data synthesis}

We used the Review Manager (RevMan) 5.4 software [20] to curate and analyse the data. We entered the number of people with an event or, the count of events and the number of participants in each comparator group for each outcome of interest into the software and generated outputs depending on the outcomes; risk or rate ratios based on intention-to-treat analysis was adopted. The full methodology on how this is conducted is available in the Cochrane Handbook of systematic reviews. [21]

Quality Assessment

One author assessed the certainty of the evidence. In contrast, a second author checked for accuracy using the Grading of Recommendations Assessment, Development and Evaluation (GRADE) considerations (study limitations, consistency of effect, imprecision, indirectness, and publication bias) as it related to the studies which contributed data for the prespecified outcomes. [22] The primary outcomes included the incidence of severe TB presentations (meningitis, pericarditis, miliary) and the incidence of active TB (pulmonary and extrapulmonary). Secondary outcomes included latent $\mathrm{TB}$ infection (definition of terms are available in Appendix 2), co-infection with HIV, antibody and cellular immune response markers, and all-cause mortality. The certainty of the evidence was assessed using GRADE criteria, [23] and are presented in the summary of findings tables (Appendices 3 and 4).

\section{Results}

The initial search returned 576 articles and 77 registered trials. A search of the reference lists produced three additional studies, while the updated search yielded additional 37 articles and six registered trials. After removing duplicates, we screened the titles and abstracts of 590 records for eligibility, and this resulted in 14 selected articles from which two studies were excluded after a full-text review. We included twelve articles, reporting six trials, after assessing the full-text articles. Five trials, [24, 26-28, 30] were individually randomised, while one [29] was a cluster-randomised controlled trial. Ten of the 12 included articles were multiple publications [25, $31,32,33,34,35]$ based on four included studies. [24, 26, 27, 29] This is shown in the PRISMA flow diagram (Figure 1). We also identified three eligible registered trials, ${ }^{[36-38]}$ listed as completed. When contacted, the trial authors reported that the data had not been analysed. 


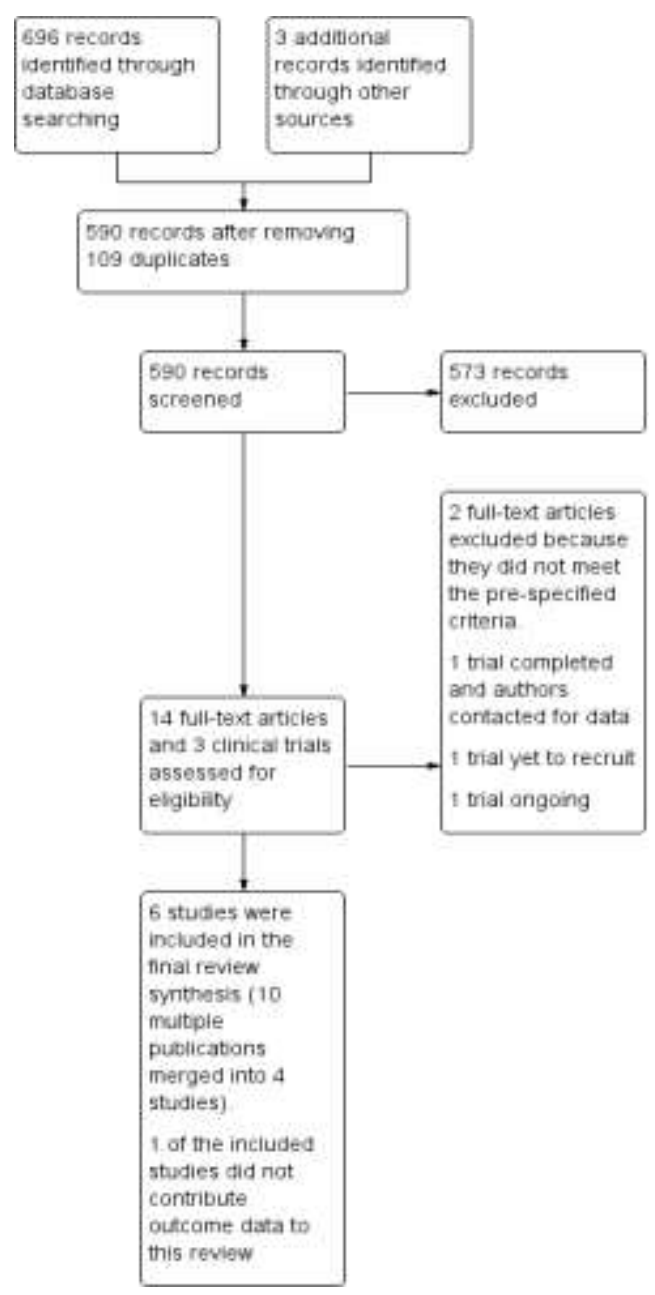

Figure 1: PRISMA Flow diagram

Two trials were conducted in Brazil, ${ }^{[27,29]}$ one in Guinea-Bissau, [28] one in Malawi, [24] and two in South Africa, [26, 30] (Table I). All participants had received the primary $B C G$ vaccination.

\section{Risk of bias assessment (Figure 2)}

Randomisation sequence: We rated five studies, [24, 26, 28-30] as having a low risk of bias and one study, ${ }^{[27]}$ having unclear risk of bias based on the description of the methods for generating the randomisation sequence in the trial.

Allocation concealment: We rated two studies as having a low risk of bias, $[24,26]$ and others as having unclear risk of bias regarding their description of the methods used in concealing allocation of participants into the trial arms.

Performance bias: We rated three of the six studies as low risk for performance bias because participants and personnel were blinded to vaccine assignments. [24, 26, 28] We rated the remaining studies to have a high risk of bias for this domain. [27, 29, 30]

Detection bias: We assessed four studies [24, 26, 28, ${ }^{29]}$ as having a low risk for detection bias, while two studies $[27,30]$ were assessed as having unclear risk for detection bias because no information was provided. 
Table I: Summarised characteristics of the included studies

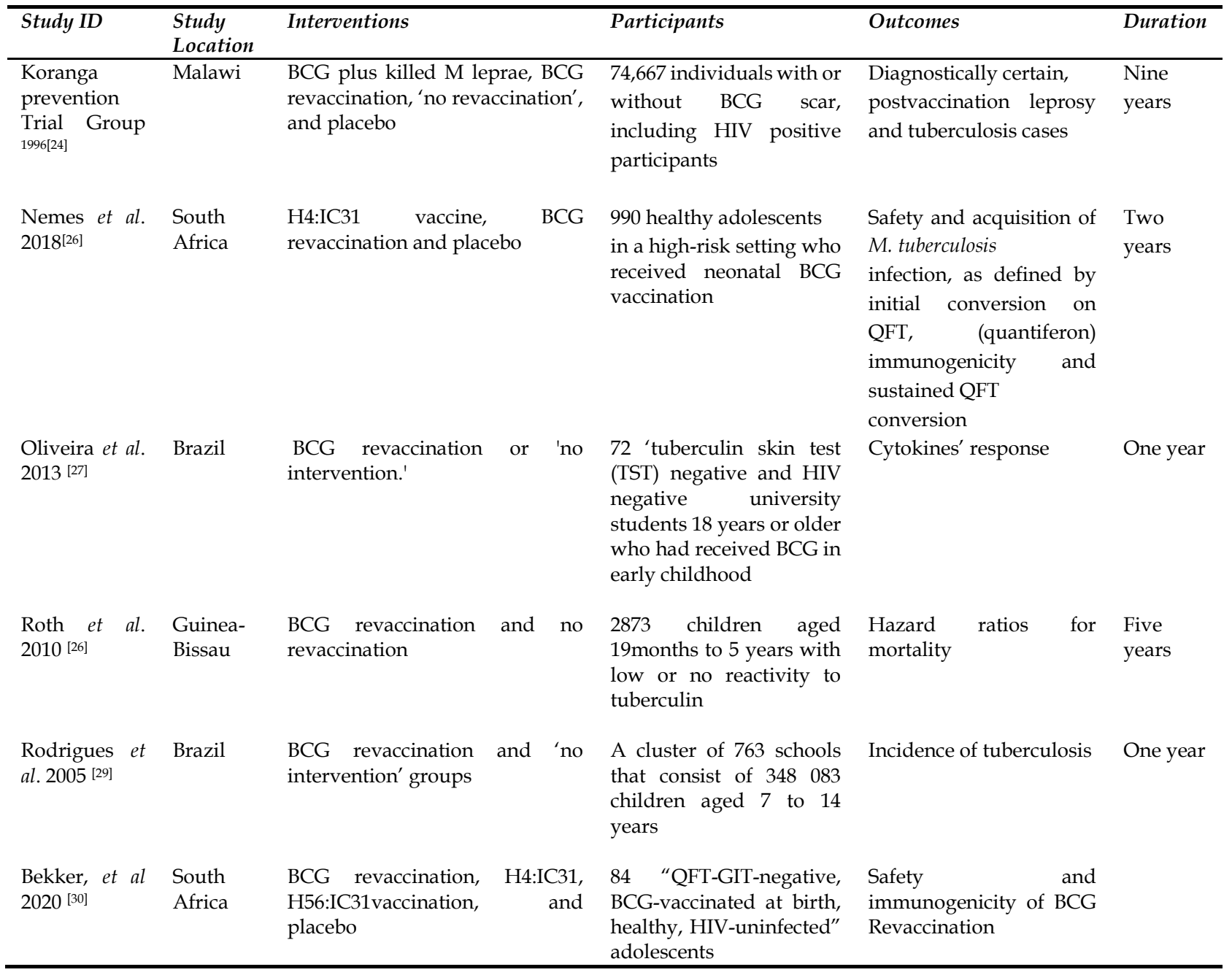

Attrition bias: We assessed five studies [24, 26, 28-30] as having a low risk for attrition bias, while one study, [27], was rated as having an unclear risk of bias because no information was provided to assess attrition.

Selective reporting: We rated two of the included studies, $[27,29]$ as having unclear risk of bias for this domain because their study protocols were not available to verify that all outcomes proposed in their protocols were reported.
We rated two included studies as having a high risk for 'other potential sources of bias'. ${ }^{[27,29]}$ In one trial, there was a reported increase in deaths following "unexpected vaccinations given during one of the trials"; this was reported with no further information to explain how the unexpected vaccination was delivered. [27] The second study was not designed or powered to make comparisons between the immune responses to each vaccine or placebo. [29] 


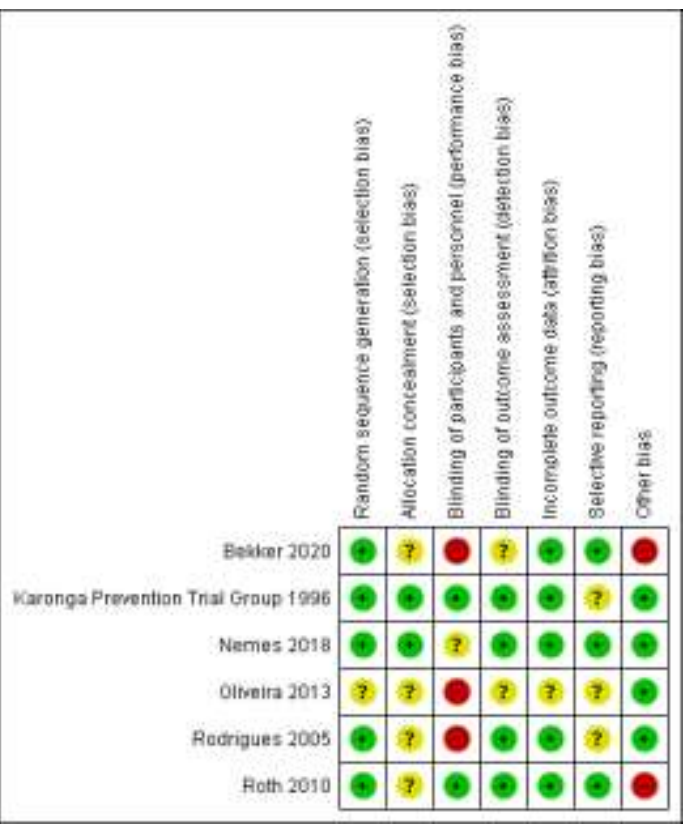

= Low risk of bias; $=$ High risk of bias; ?= unclear risk of bias Figure 2: Risk of bias assessment of included studies

\section{Effects of interventions}

Three trials compared the effect of BCG revaccination to 'no revaccination' [25-27], but data were only available for two of these studies. [28, 29] Three trials compared BCG revaccination to placebo. $[24,26,30]$

\section{BCG revaccination versus 'no revaccination' (Primary BCG vaccination alone)}

Primary outcomes

The risk of active TB infection at 5-years postrevaccination was not significantly different between study arms (RR 1.16, 95\% CI 0.88 to 1.51 ; 348,083 participants; one study, moderate certainty evidence). At nine years postintervention, the risks of active pulmonary $\mathrm{TB}$ (RR 0.96, 95\% CI 0.82 to $1.12 ; 348,083$ participants; one study, moderate certainty evidence) and extrapulmonary TB (RR 0.71, 95\% CI 0.43 to 1.16; 348,083 participants; one study, moderate certainty evidence) were not significantly different between the trial arms. [29]

\section{Secondary outcomes}

Immunological response

Cellular immune responses: One study reported a detectable IFN- $Y$ concentration in response to PPD in $80 \%$ of participants in the BCG revaccination group compared to $46 \%$ in the control group $(p<0.001)$. [29] There was also a slight increase in the levels of IFN-Y in response to PPD (Geometric Mean Ratio (GMR 4.54, 95\% CI 3.13-6.58, 345 participants; one study, low certainty evidence) following revaccination. There was no difference in Interleukin (IL)-13 levels in response to revaccination (GMR $=1.43$ (Cl 1.00 to 2.05, 345 participants; one study). There was no difference in IFN-Y and IL-13 responses to phytohaemagglutinin (PHA) between arms.

All-cause mortality was not significantly different between trial arms (RR 1.20, 95\% CI 0.77 to 1.86; 2871 participants; one study, moderate certainty evidence). No studies reported on the effect of revaccination on latent TB infections.

Adverse events: In all, 24 events were reported in the intervention group compared to 14 in control (RR 1.71, 95\% CI 0.90 to 3.27; 800 participants; one study, low certainty evidence). There was no difference between the intervention groups. The risk of a local reaction at the vaccination site was higher following 
revaccination ( $\mathrm{RR} 43.00,95 \% \mathrm{CI} 2.61$ to 707.43 ; 800 participants; one study, low certainty evidence). The wide confidence intervals are due to the small number of reports; 21 participants in the intervention arm (Appendix 3). [28]

\section{BCG revaccination versus placebo}

\section{Primary outcomes}

The risk of developing active pulmonary TB was higher in the revaccination group compared to the placebo group (RR 1.74, 95\% CI 1.00 to 3.01; 46764 participants; one study). ${ }^{[24]}$ However, there was no significant difference in the risk of developing active extrapulmonary TB between the trial arms (RR 0.55, 95\% CI 0.19 to $1.65 ; 46764$ participants; one study).

\section{Secondary outcomes}

Incidence of latent TB: The effect of revaccination on the incidence of latent TB varied between some reductions in risk to an increased risk. Overall, the risk was not significantly different between the intervention and placebo arms (RR $0.84,95 \%$ CI 0.62 to $1.15 ; 695$ participants; two studies, $\mathrm{I}^{2}=0 \%$ low certainty evidence) (Figure 3). $[26,30]$

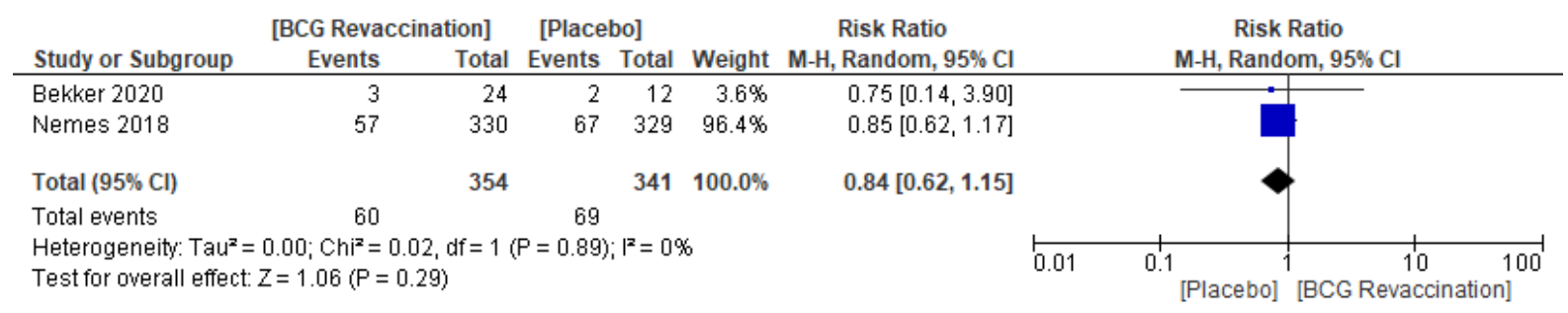

Figure 3: Forest plot showing the effect of BCG revaccination versus Placebo on the incidence of latent TB

TB/HIV co-infection: The risk of TB/HIV coinfection was higher in the revaccination arm than the placebo arm (RR 13.91, 95\% CI 1.83 to 105.78; 46764 participants; one study). [24]

The risk of any adverse events was higher in the revaccination arm (RR 2.65, 95\% CI 1.68 to 4.17; participants $=695$; two studies, $\mathrm{I}^{2}=62 \%$, low certainty evidence), but the risk of serious adverse events was not significantly different between the arms (RR $0.5095 \%$ CI 0.05 to 5.47; 659 participants; one study, low certainty evidence) (Figure 4). [26, 30]

The risk of all-cause mortality was not significantly different between the trial arms (RR 0.33, 95\% CI 0.01 to 8.13 ; 659 participants; one study, low certainty evidence) (Appendix 4).

None of the included studies reported the incidence of severe presentations of $\mathrm{TB}$, and no studies reported the effect of revaccination on latent TB infections.

\section{Discussion}

In this review, we summarised the evidence of the effect of BCG revaccination for preventing TB in LMICs. We included results from six RCTs, five of which were conducted in sub-Saharan Africa. The key findings in the review included the fact that BCG revaccination probably makes little difference to the risk of active TB infection compared to primary vaccination alone or placebo, even when assessed at five- or nine years post-vaccination. BCG revaccination also probably makes little difference to the incidence of latent TB. The assessment of the effect on markers of cellular immune response to exposure showed variable effects, with the evidence judged as having low certainty. Also, BCG revaccination may make little or no difference in the risk of TB/HIV co-infection, adverse events, and all-cause mortality. There was no available evidence for the effect of BCG revaccination on 
the risk of severe forms of $\mathrm{TB}$ such as miliary spread or meningitis. Overall, the evidence is based on five studies while the effect on the assessed outcomes was judged to be of low to moderate certainty and, most studies showed a high or unclear risk of bias for most of the criteria assessed.

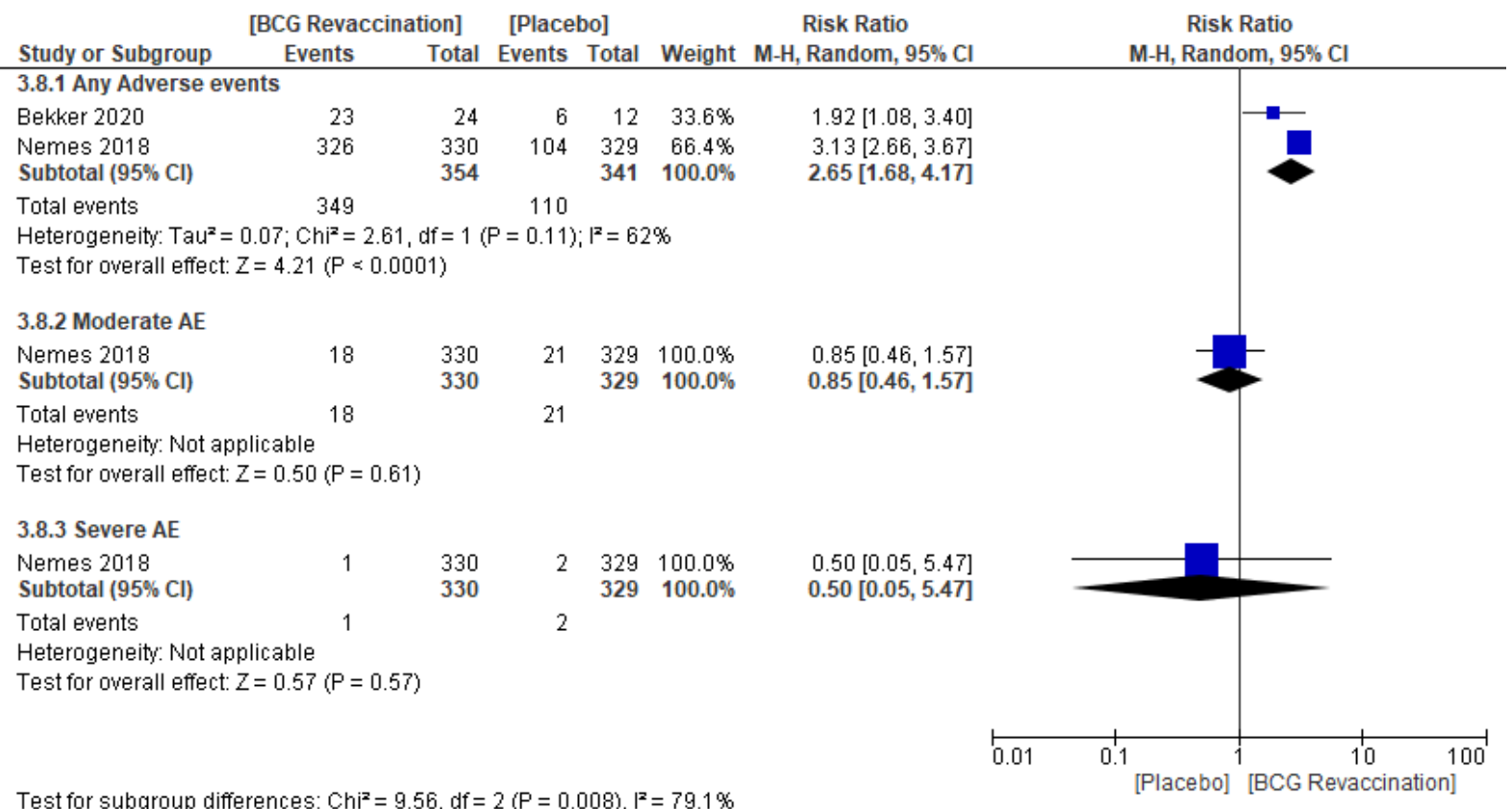

Figure 4: Forest plot of the adverse effect of BCG revaccination versus placebo

From the evidence above, BCG revaccination may make little or no difference in reducing the burden of TB in sub-Saharan Africa. However, this is based on few studies with considerable variation in design and quality. This indicates that additional studies with clear outcomes and design are needed.

The findings are consistent with a previous systematic review, ${ }^{[39]}$ which also reported the lack of evidence of the protective effect of BCG revaccination. The current review provides a formal assessment of the risk of bias and the certainty of the evidence in the available studies that have addressed this question. Due to the high burden of TB infection in endemic countries, young children are often exposed to the infection very early, and this risk increases with age. High infection rates make it challenging to distinguish the effect of revaccination from incidental exposure, as shown by the wide range of effects of the assessed immune response markers. [40] Therefore, the effect of a booster vaccination on TB infection is likely to be underestimated.

The risk of $\mathrm{TB}$ is still high in HIV-positive individuals relative to the general population despite the increased access to HIV treatment in sub-Saharan Africa. [41] HIV infection has been associated with an increased risk of reactivation of latent TB, development of severe forms of TB and increased risk of TB-associated deaths compared to the general population; hence, HIV infection may confound the effect of BCG revaccination and may be contraindicated in these populations. ${ }^{[42]}$ One of the included studies reported an increased risk of active pulmonary $\mathrm{TB}$ in the revaccination arm compared to the placebo arm. [24] The authors of that study attributed this to a disproportionate allocation of 
HIV-positive participants in the trial to the BCG revaccination group. However, it was not clear from the trial report whether the $\mathrm{CD} 4$ counts and viral load of the HIV-positive participants were measured at baseline before the intervention. Therefore, this finding may not be generalisable to populations with HIV infection. The findings were also characterised by moderate to low certainty due to a high or unclear risk of bias and imprecision.

Study limitation: Only six studies were included in this review, but five of these contributed outcome data. The data from few ongoing trials could change our certainty in the evidence for outcomes measured in this current review.

\section{Conclusion}

The available evidence suggests that BCG revaccination may have little or no effect on preventing TB infection in LMICs. These findings are based on studies with a high to unclear risk of bias in their design and the low to moderate certainty of evidence. Well-designed studies with clear outcomes of public health importance should be considered. Background studies are also needed to refine measurements of outcomes in different at-risk populations that would feed into the design of these pragmatic studies.

Declaration: The listed authors are members of the Effective Healthcare Alliance Programme of the Institute of Tropical Diseases Research, University of Calabar Teaching Hospital, Calabar, Nigeria.

Acknowledgement: We acknowledge the contribution of Chukwudi Oringanje of Cochrane Nigeria to assist the research team during the priority setting exercise that produced this review. We also acknowledge Dr Ifedayo Adetifa for his comments and suggestions while conducting the systematic review.

Authors' Contributions: MMM, OOA, EEE conceived the research idea. $\mathrm{MJ}$ and OAO drafted the study protocol. EEB designed the search strategy and searched the literature for relevant studies. ADI and
SA screened the studies for eligibility. CM and MC extracted data while OOA resolved disagreements. OOA analysed the data and graded the certainty of the evidence while EEB cross-checked for accuracy. OJ wrote the first draft of the manuscript. All the authors reviewed the initial draft and approved the final version of the manuscript.

Conflict of Interest: None.

Funding: Self-funded.

Publication History: Submitted 31 May 2021; Accepted 05 August 2021.

\section{References}

1. Houben RM, Dodd PJ. The global burden of latent tuberculosis infection: a re-estimation using mathematical modelling. PLoS Med 2016; 13: e1002152. https://doi.org/10.1371/journal.pmed.1002 $\underline{152}$

2. World Health Organization. Tuberculosis. https://www.who.int/news-room/factsheets/detail/tuberculosis. 2019. (Accessed 16 March 2020).

3. World Health Organization. Global Tuberculosis Report 2019. https://www.who.int/tb/publications/glob al_report/tb19_Report_regional_global_15O ctober2019.pdf?ua=1. 2019. (Accessed 16 March 2020).

4. Pawlowski A, Jansson M, Sköld M, Rottenberg ME, Källenius G. Tuberculosis and HIV co-infection. PLoS Pathog. 2012; 8(2): e1002464. https://doi.org/10.1371/journal.ppat.10024 $\underline{64}$

5. Chai Q, Zhang Y, Liu CH. Mycobacterium tuberculosis: An Adaptable Pathogen Associated with Multiple Human Diseases. Front Cell Infect Microbiol 2018; 8(158). https://doi.org/10.3389/fcimb.2018.00158

6. Bendinelli M, Friedman $\mathrm{H}$, eds. Mycobacterium Tuberculosis: Interactions with the Immune System. Springer. US. 1988. 
7. Lönnroth K, Raviglione $\mathrm{M}$. The WHO's new End TB Strategy in the post-2015 era of the Sustainable Development Goals. Trans Royal Soc Trop Med Hyg 2016; 110: 148 150. https://doi.org/10.1093/trstmh/trv108

8. Cruz A, Starke J. Tuberculosis. Feigin and Cherry's textbook of paediatric infectious diseases. In Cherry J, Harrison G, Kaplan S, Steinbach W, Hotez P (Ed). 7th Edition. Philadelphia, PA.: Elsevier Saunders. 2014; 1335-1380.

9. Mansoor N, Scriba TJ, de Kock M, Tameris M, Abel B, Keyser A, et al. HIV-1 infection in infants severely impairs the immune response induced by Bacille Calmette-Guerin vaccine. J Infect Dis 2009; 199: 982-990. https://doi.org/10.1086/597304

10. Jeon CY, Murray MB. Diabetes mellitus increases the risk of active tuberculosis: a systematic review of 13 observational studies. PLoS Med 2008; 5: e152. https://doi.org/10.1371/journal.pmed.0050 152.

11. Dunn JJ, Starke JR, Revell PA. Laboratory diagnosis of Mycobacterium tuberculosis infection and disease in children. J Clin Microbiol 2016; 54: 1434-1441. https://doi.org/10.1128/JCM.03043-15

12. Dalmia N, Ramsay AJ. Prime-boost approaches to tuberculosis vaccine development. Expert Rev Vaccines 2012; 11: 1221-1233. https://doi.org/10.1586/erv.12.94

13. World Health Organization. BCG vaccines: WHO Position Papers - February 2018. Weekly Epidemiological Rec No. 8, 2018; 93: 73-96. (Accessed on 08 October 2020).

14. Roy A, Eisenhut M, Harris RJ, Rodrigues LC, Sridhar S, Habermann S, et al. Effect of BCG vaccination against Mycobacterium tuberculosis infection in children: systematic review and meta-analysis. BMJ 2014; 349: g4643. https://doi.org/10.1136/bmj.g4643

15. Abubakar I, Pimpin L, Ariti C, Beynon R, Mangtani P, Sterne JA, et al. Systematic review and meta-analysis of the current evidence on the duration of protection by bacillus Calmette-Guérin vaccination against tuberculosis. Health Technology Assessment (Winchester, England) 2013; 17: 1. https://doi.org/10.3310/hta17370

16. Rakshit S, Ahmed A, Adiga V, Sundararaj BK, Sahoo PN, Kenneth J, et al. BCG revaccination boosts adaptive polyfunctional Th1/Th17 and innate effectors in IGRA+ and IGRAIndian adults. J Clin Invest Insight 2019; 4(24). https://doi.org/10.1172/jci.insight.130540

17. Effa EE, Oduwole O, Schoonees A, Hohlfeld A, Durao S, Kredo T, et al. Priority setting for new systematic reviews: processes and lessons learned in three regions in Africa. BMJ Global Health. 2019; 4: e001615. http://dx.doi.org/10.1136/bmigh-2019$\underline{001615}$

18. Oduwole O, Mwankon JP, Okebe J, Sallahdeen A, Esu BE, Effa EE, et al. Booster dose of Bacille Calmette-Guerin vaccine for tuberculosis in low- and middle-income countries. PROSPERO 2018. CRD42018095107 Available from: https://www.crd.york.ac.uk/prospero/disp lay_record.php?ID=CRD42018095107

19. How does the World Bank classify countries? https://datahelpdesk.worldbank.org/kno wledgebas

20. Cochrane Collaboration. Review manager (RevMan) [Computer Program]. Copenhagen: The Nordic Cochrane Centre. 2014.

21. Higgins JPT, Deeks JJ, Altman DG, (Editors). Cochrane Handbook for Systematic Reviews of Interventions Version 5.1.0 (updated March 2011). The Cochrane Collaboration, 2011. Available from handbook.cochrane.org 
22. Atkins D, Best D, Briss PA, Eccles M, FalckYtter Y, Flottorp S. Grading quality of evidence and strength of recommendations. BMJ 2004; 328 : 1490. https://doi.org/10.1136/bmj.328.7454.1490 GRADEproGD

23. GRADEpro Guideline Development Tool [Software]. McMaster University. 2015. https://gdt.gradepro.org/app/

24. Karonga Prevention Trial Group. Randomised controlled trial of single BCG, repeated BCG, or combined BCG and killed Mycobacterium leprae vaccine for prevention of leprosy and tuberculosis in Malawi. The Lancet. 1996; 348: 17-24.

25. Fine PE, Ponnighaus JM. Background, design and prospects of the Karonga Prevention Trial, a leprosy vaccine trial in northern Malawi. Trans Royal Soc Trop Med Hyg 1988; 82: 810-817. https://doi.org/10.1016/00359203(88)90003-X.

26. Nemes E, Geldenhuys H, Rozot V, Rutkowski KT, Ratangee F, Bilek N, et al. Prevention of M. tuberculosis infection with H4: IC31 vaccine or BCG revaccination. New Engl J Med 2018; 379: 138-149. https://doi.org/10.1056/NEJMoa1714021

27. Oliveira ES, Marinho JM, Barbosa T. Interferon-gamma production by mononuclear cells in Bacille CalmetteGuérin-revaccinated healthy volunteers predicted long-term antimycobacterial responses in a randomised controlled trial. Vaccine. 2013; 31: 3778-3782. https://doi.org/10.1016/j.vaccine.2013.04.07 $\underline{9}$

28. Roth AE, Benn CS, Ravn H, Rodrigues A, Lisse IM, Yazdanbakhsh M, et al. Effect of revaccination with BCG in early childhood on mortality: randomised trial in Guinea-Bissau. BMJ 2010; 340: c671. https://doi.org/10.1136/bmj.c671

29. Rodrigues LC, Pereira SM, Cunha SS, Genser
B, Ichihara MY, de Brito SC, et al. Effect of $\mathrm{BCG}$ revaccination on incidence of tuberculosis in school-aged children in Brazil: the BCG-REVAC cluster-randomised trial. The Lancet 2005; 366: 1290-1295. https://doi.org/10.1016/S0140$\underline{6736(05) 67145-0}$

30. Bekker LG, Dintwe O, Fiore-Gartland A, Middelkoop K, Hutter J, et al. A phase $1 \mathrm{~b}$ randomised study of the safety and immunological responses to vaccination with H4: IC31, H56: IC31, and BCG revaccination in Mycobacterium tuberculosis-uninfected adolescents in Cape Town, South Africa. EClinical Medicine 2020: 100313. https://doi.org/10.1016/j.eclinm.2020.10031 3

31. Barreto ML, Pereira SM, Pilger D, Cruz AA, Cunha SS, Sant'Anna C, et al. Evidence of an effect of BCG revaccination on incidence of tuberculosis in school-aged children in Brazil: second report of the BCG-REVAC clusterrandomised trial. Vaccine 2011; 29: 4875-4877. https://doi.org/10.1016/j.vaccine.2011.05.02 $\underline{3}$

32. Dourado I, Rios MH, Pereira SM, Cunha SS, Ichihara MY, Goes JC, et al. Rates of adverse reactions to first and second doses of BCG vaccination: results of a large community trial in Brazilian schoolchildren. Int J Tuberc Lung Dis 2003; 7: 399-402.

33. Barreto ML, Rodrigues LC, Cunha SS, Pereira S, Hijjar MA, Ichihara MY, et al. design of the Brazilian BCG-REVAC trial against tuberculosis: a large, simple randomised community trial to evaluate the impact on tuberculosis of BCG revaccination at school age. Controlled Clin Trials 2002; 23: 540-553. https://doi.org/10.1016/S0197$\underline{\text { 2456(02)00216-7 }}$

34. Peleteiro TS, Oliveira ES, Conceição EL, Nascimento-Sampaio F, Alcântara-Neves $\mathrm{NM}$, Mendes CM, et al. Impact of Bacille Calmette-Guérin revaccination on serum IgE levels in a randomized controlled trial. 
Revista da Sociedade Brasileira de Medicina Tropical 2018; 51: 94-98. https://doi.org/10.1590/0037-8682-0081$\underline{2017}$

35. Andersen A, Roth A, Jensen KJ, Erikstrup C, Lisse IM, Whittle $\mathrm{H}$, et al. The immunological effect of revaccination with Bacille CalmetteGuérin vaccine at 19 months of age. Vaccine 2013; 31: 2137-2144. https://doi.org/10.1016/j.vaccine.2013.02.05 $\underline{0}$

36. Fine P. Does giving a second BCG vaccination or adding a leprosy vaccine to BCG vaccination provide additional protection against leprosy and tuberculosis, compared with giving a single BCG vaccination? International Standard Randomised Controlled Trial Number Registry, 2019. http://www.who.int/trialsearch/Trial2.asp $\underline{\mathrm{x} \text { ?TrialID=ISRCTN11311670. }}$ Accessed 16 March 2020.

37. Hill P. Bacillus Calmette Guerin (BCG) vaccination/revaccination for prevention of Mycobacterium tuberculosis infection in healthcare students entering clinical training: a randomised placebo-controlled proof of principle trial (PoP BCG trial). Australian New Zealand Clinical Trials Registry, 2019. http://www.who.int/trialsearch/Trial2.asp $\mathrm{x}$ ?TrialID=ACTRN12619001327178
Accessed 16 March 2020.

38. Gates MRI. BCG Revaccination of Healthy Adolescents for the Prevention of Mycobacterium Tuberculosis Sustained Infection. Clinical Trials.gov. 2019. https://clinicaltrials.gov/show/NCT041521 61 Accessed 16 March 2020.

39. Barreto ML, Pereira SM, Ferreira AA. BCG vaccine: efficacy and indications for vaccination and revaccination. J Pediatr (Rio J) 2006; 82: S45-S54.

40. Dodd PJ, Gardiner E, Coghlan R, Seddon JA. Burden of childhood tuberculosis in 22 highburden countries: a mathematical modelling study. The Lancet Global Health 2014; 2: e4539.

41. Hesseling AC, Cotton MF, Jennings $\mathrm{T}$, Hesseling AC, Cotton MF, Jennings $\mathrm{T}$, et al. High incidence of tuberculosis among HIVinfected infants: evidence from a South African population-based study highlights the need for improved tuberculosis control strategies. Clin Infect Dis 2009; 48: 108-114

42. Whitaker JA. Immunisation Strategies to Span the Spectrum of Immunocompromised Adults. In: Mayo Clinic Proceedings. 2020; 95: 1530-1548. 
Appendix 1: Search strategy

(PubMed Search: Updated search on 20 August 2018)

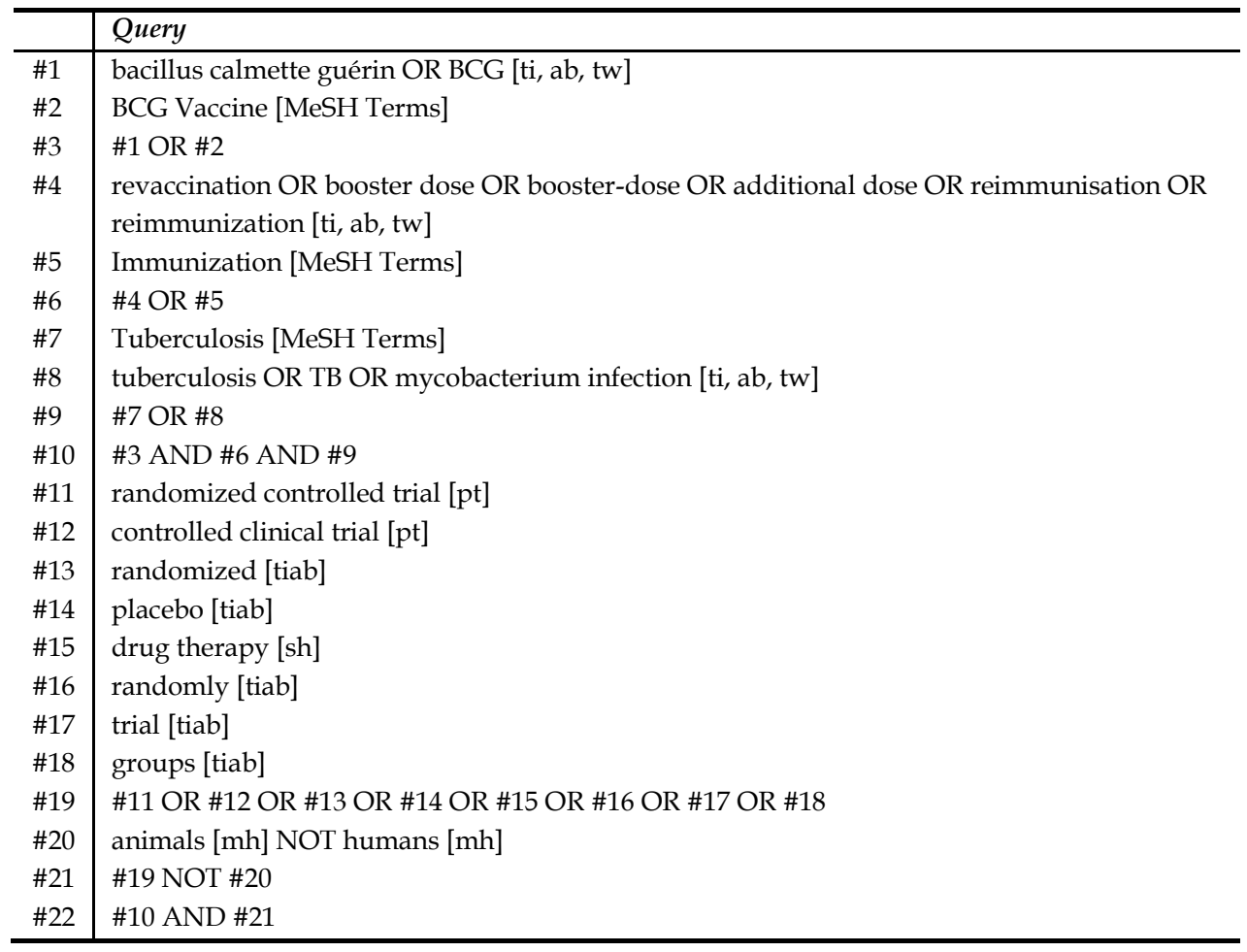

\section{Appendix 2: Definition of terms}

\begin{tabular}{|c|c|}
\hline Term & Definition \\
\hline Primary & Initial infection with Mycobacterium tuberculosis organism, usually at a single focus. It rarely causes \\
\hline Tuberculosis & acute illness, being largely asymptomatic. \\
\hline Latent (Dormant) & This is the stage of tuberculosis infection following primary infection; in most (95\%) cases, the tubercle \\
\hline Tuberculosis & $\begin{array}{l}\text { bacilli remain inactive. It is an asymptomatic phase, and infection transmission of tubercle bacilli does } \\
\text { not happen except in immunocompromised individuals. }\end{array}$ \\
\hline Active Tuberculosis & $\begin{array}{l}\text { This refers to a situation whereby latent tuberculosis infection reactivates with symptoms and signs of } \\
\text { disease. }\end{array}$ \\
\hline $\begin{array}{l}\text { Pulmonary } \\
\text { Tuberculosis }\end{array}$ & $\begin{array}{l}\text { This refers to tuberculosis of the lungs. It is the major form of tuberculosis. Pulmonary tuberculosis is } \\
\text { suspected when patients present with cough, fever, weight loss and night sweats. Diagnosis is made } \\
\text { based on positive sputum smear, GeneXpert test and Chest X-ray findings typical of tuberculosis. }\end{array}$ \\
\hline $\begin{array}{l}\text { Extrapulmonary } \\
\text { Tuberculosis } \\
\text { Severe Tuberculosis }\end{array}$ & $\begin{array}{l}\text { This refers to TB outside the lungs. It usually follows blood spread from the lungs to other organs or } \\
\text { tissues like epiphyses of long bones, vertebral bodies, kidneys, meninges and others. } \\
\text { This includes TB meningitis and Miliary tuberculosis. }\end{array}$ \\
\hline
\end{tabular}

Citation: Heemskerk D, Caws M, Marais B, Farrar J. Pathogenesis. In: Tuberculosis in Adults and Children. Springer, Cham. 2015. pp. 9-16. 
Appendix 3: Summary of findings table showing BCG Revaccination compared to BCG (No revaccination) for preventing tuberculosis

Patient or population: preventing tuberculosis

Setting:

Intervention: BCG Revaccination

Comparison: BCG (No revaccination)

\begin{tabular}{|c|c|c|c|c|c|c|}
\hline \multirow[t]{2}{*}{ Outcomes } & \multicolumn{2}{|c|}{$\begin{array}{l}\text { Anticipated absolute effects } \\
\qquad(95 \% \mathrm{CI})\end{array}$} & \multirow{2}{*}{$\begin{array}{c}\text { Relative } \\
\text { effect } \\
(95 \% \\
\text { CI) }\end{array}$} & \multirow{2}{*}{$\begin{array}{c}\text { № of } \\
\text { participants } \\
\text { (studies) }\end{array}$} & \multirow{2}{*}{$\begin{array}{c}\text { Certainty of } \\
\text { the evidence } \\
\text { (GRADE) }\end{array}$} & \multirow[t]{2}{*}{ Comments } \\
\hline & $\begin{array}{c}\text { Risk with } \\
\text { BCG } \\
\text { (No } \\
\text { revaccination) }\end{array}$ & $\begin{array}{c}\text { Risk with } \\
\text { BCG } \\
\text { Revaccination }\end{array}$ & & & & \\
\hline $\begin{array}{l}\text { Active TB } \\
\text { (Pulmonary TB) - } \\
\text { Six months to Five } \\
\text { years }\end{array}$ & 57 per 100,000 & $\begin{array}{l}66 \text { per } 100,000 \\
(50 \text { to } 86)\end{array}$ & $\begin{array}{l}\text { RR } 1.16 \\
(0.88 \text { to } \\
1.51)\end{array}$ & $\begin{array}{l}348083 \\
(1 \mathrm{RCT})\end{array}$ & $\begin{array}{c}\oplus \oplus \oplus \bigcirc \\
\text { MODERATE, } \\
{[29], \mathrm{a}}\end{array}$ & \\
\hline $\begin{array}{l}\text { Active TB } \\
\text { (Pulmonary TB) - } \\
\text { Nine years }\end{array}$ & $\begin{array}{l}187 \text { per } \\
100,000\end{array}$ & $\begin{array}{c}179 \text { per } \\
100,000 \\
(153 \text { to } 209)\end{array}$ & $\begin{array}{l}\text { RR } 0.96 \\
(0.82 \text { to } \\
1.12)\end{array}$ & $\begin{array}{l}348083 \\
(1 \mathrm{RCT})\end{array}$ & $\begin{array}{c}\oplus \oplus \oplus \bigcirc \\
\text { MODERATE, } \\
\text { [29], a }\end{array}$ & \\
\hline $\begin{array}{l}\text { Active TB } \\
\text { (Non-pulmonary } \\
\text { TB) }\end{array}$ & 22 per 100,000 & $\begin{array}{l}15 \text { per } 100,000 \\
(9 \text { to } 25)\end{array}$ & $\begin{array}{c}\text { RR } 0.71 \\
(0.43 \text { to } \\
1.16)\end{array}$ & $\begin{array}{l}348083 \\
(1 \mathrm{RCT})\end{array}$ & $\begin{array}{c}\oplus \oplus \oplus \bigcirc \\
\text { MODERATE, } \\
{[29], \text { a }}\end{array}$ & \\
\hline All-cause mortality & 24 per 1,000 & $\begin{array}{l}29 \text { per } 1,000 \\
(19 \text { to } 45)\end{array}$ & $\begin{array}{l}\text { RR } 1.20 \\
(0.77 \text { to } \\
1.86)\end{array}$ & $\begin{array}{c}2871 \\
(1 \mathrm{RCT})\end{array}$ & $\begin{array}{c}\oplus \oplus \oplus \bigcirc \\
\text { MODERATE, } \\
{[28], \mathrm{b}}\end{array}$ & \\
\hline $\begin{array}{l}\text { (Cytokines) } \\
\text { Cellular immune } \\
\text { responses }\end{array}$ & $\begin{array}{l}\text { The mean } \\
\text { (cytokines) } \\
\text { cellular } \\
\text { immune } \\
\text { responses was } \\
0\end{array}$ & $\begin{array}{c}\text { MD } 0.09 \\
\text { lower } \\
\text { (0.23 lower to } \\
0.05 \text { higher) }\end{array}$ & - & $\begin{array}{c}2871 \\
(1 \mathrm{RCT})\end{array}$ & $\begin{array}{c}\oplus \oplus \oplus \bigcirc \\
\text { MODERATE, } \\
{[28], \mathrm{b}}\end{array}$ & \\
\hline $\begin{array}{l}\text { (Cytokines) Cellular } \\
\text { immune responses - } \\
\text { TNF- a }\end{array}$ & $\begin{array}{l}\text { The mean } \\
\text { (cytokines) } \\
\text { cellular } \\
\text { immune } \\
\text { responses - } \\
\text { TNF- a was } 0\end{array}$ & $\begin{array}{c}\text { MD } 1.03 \\
\text { higher } \\
\text { (0.81 higher to } \\
1.25 \text { higher) }\end{array}$ & - & $\begin{array}{c}2871 \\
(1 \mathrm{RCT})\end{array}$ & $\begin{array}{c}\oplus \oplus \oplus \bigcirc \\
\text { MODERATE, } \\
{[28], \mathrm{b}}\end{array}$ & \\
\hline
\end{tabular}


Appendix 3: Summary of findings table showing BCG Revaccination compared to BCG (No revaccination) for preventing tuberculosis

Patient or population: preventing tuberculosis

Setting:

Intervention: BCG Revaccination

Comparison: BCG (No revaccination)

\begin{tabular}{|c|c|c|c|c|c|c|}
\hline \multirow[t]{2}{*}{ Outcomes } & \multicolumn{2}{|c|}{$\begin{array}{l}\text { Anticipated absolute effects }{ }^{*} \\
\qquad(95 \% \mathrm{CI})\end{array}$} & \multirow{2}{*}{$\begin{array}{l}\text { Relative } \\
\text { effect } \\
(95 \% \\
\text { CI })\end{array}$} & \multirow{2}{*}{$\begin{array}{c}\text { № of } \\
\text { participants } \\
\text { (studies) }\end{array}$} & \multirow{2}{*}{$\begin{array}{c}\text { Certainty of } \\
\text { the evidence } \\
\text { (GRADE) }\end{array}$} & \multirow[t]{2}{*}{ Comments } \\
\hline & \begin{tabular}{|c|} 
Risk with \\
BCG \\
(No \\
revaccination)
\end{tabular} & $\begin{array}{c}\text { Risk with } \\
\text { BCG } \\
\text { Revaccination }\end{array}$ & & & & \\
\hline $\begin{array}{l}\text { (Cytokines) Cellular } \\
\text { immune responses - } \\
\text { Interleukin- } 13 \text { (IL- } \\
\text { 13) }\end{array}$ & $\begin{array}{l}\text { The mean } \\
\text { (cytokines) } \\
\text { cellular } \\
\text { immune } \\
\text { responses - } \\
\text { Interleukin- } \\
13 \text { (IL-13) was } \\
0\end{array}$ & $\begin{array}{c}\text { MD } 1.11 \\
\text { higher } \\
\text { (0.71 higher to } \\
1.51 \text { higher) }\end{array}$ & - & $\begin{array}{c}2871 \\
(1 \mathrm{RCT})\end{array}$ & $\begin{array}{c}\oplus \oplus \oplus \bigcirc \\
\text { MODERATE, } \\
{[28], \mathrm{b}}\end{array}$ & \\
\hline $\begin{array}{l}\text { (Cytokines) Cellular } \\
\text { immune responses - } \\
\text { Interferon (IFN)- } \gamma\end{array}$ & $\begin{array}{l}\text { The mean } \\
\text { (cytokines) } \\
\text { cellular } \\
\text { immune } \\
\text { responses - } \\
\text { interferon } \\
\text { (IFN)- } \gamma \text { was } 0\end{array}$ & $\begin{array}{c}\text { MD } 1.06 \\
\text { lower } \\
\text { (1.41 lower to } \\
0.71 \text { lower) }\end{array}$ & - & $\begin{array}{c}2871 \\
(1 \mathrm{RCT})\end{array}$ & $\begin{array}{c}\oplus \oplus \oplus \bigcirc \\
\text { MODERATE, } \\
{[28], \mathrm{b}}\end{array}$ & \\
\hline $\begin{array}{l}\text { (Cytokines) Cellular } \\
\text { immune responses - } \\
\text { Interleukin -10 (IL- } \\
\text { 10) }\end{array}$ & $\begin{array}{l}\text { The mean } \\
\text { (cytokines) } \\
\text { cellular } \\
\text { immune } \\
\text { responses - } \\
\text { Inteleukin -10 } \\
\text { (IL-10) was } 0\end{array}$ & $\begin{array}{c}\text { MD } 1.47 \\
\text { lower } \\
\text { (1.71 lower to } \\
1.23 \text { lower })\end{array}$ & - & $\begin{array}{c}2871 \\
(1 \mathrm{RCT})\end{array}$ & $\begin{array}{c}\oplus \oplus \oplus \bigcirc \\
\text { MODERATE } \\
{[28], \mathrm{b}-}\end{array}$ & \\
\hline $\begin{array}{l}\text { Adverse events: } \\
\text { Large local reaction }\end{array}$ & 0 per 100,000 & $\begin{array}{l}0 \text { per } 100,000 \\
\quad(0 \text { to } 0)\end{array}$ & $\begin{array}{c}\text { RR } \\
43.00 \\
(2.61 \text { to } \\
707.43)\end{array}$ & $\begin{array}{c}800 \\
(1 \mathrm{RCT})\end{array}$ & $\begin{array}{l}\oplus \oplus \bigcirc \bigcirc \\
\text { LOW [28],c }\end{array}$ & \\
\hline $\begin{array}{l}\text { Adverse events: } \\
\text { Axillary lymph } \\
\text { nodes ( } \geq 15 \mathrm{mmin} \\
\text { diameter) }\end{array}$ & $\begin{array}{l}3,500 \text { per } \\
100,000\end{array}$ & $\begin{array}{c}5985 \text { per } \\
100,000 \\
(3,150 \text { to } \\
11,445)\end{array}$ & $\begin{array}{l}\text { RR } 1.71 \\
(0.90 \text { to } \\
3.27)\end{array}$ & $\begin{array}{c}800 \\
(1 \mathrm{RCT})\end{array}$ & $\begin{array}{c}\oplus \oplus \oplus \bigcirc \\
\text { MODERATE } \\
{[28], c_{-}}\end{array}$ & \\
\hline
\end{tabular}


Appendix 3: Summary of findings table showing BCG Revaccination compared to BCG (No revaccination) for preventing tuberculosis

Patient or population: preventing tuberculosis

Setting:

Intervention: BCG Revaccination

Comparison: BCG (No revaccination)

\begin{tabular}{|c|c|c|c|c|c|c|}
\hline \multirow[t]{2}{*}{ Outcomes } & \multicolumn{2}{|c|}{$\begin{array}{l}\text { Anticipated absolute effects* } \\
\qquad(95 \% \mathrm{CI})\end{array}$} & \multirow{2}{*}{\begin{tabular}{|c|} 
Relative \\
effect \\
$(95 \%$ \\
CI $)$
\end{tabular}} & \multirow{2}{*}{$\begin{array}{c}\text { № of } \\
\text { participants } \\
\text { (studies) }\end{array}$} & \multirow{2}{*}{$\begin{array}{c}\text { Certainty of } \\
\text { the evidence } \\
\text { (GRADE) }\end{array}$} & \multirow[t]{2}{*}{ Comments } \\
\hline & $\begin{array}{c}\text { Risk with } \\
\text { BCG } \\
\text { (No } \\
\text { revaccination) }\end{array}$ & $\begin{array}{c}\text { Risk with } \\
\text { BCG } \\
\text { Revaccination }\end{array}$ & & & & \\
\hline
\end{tabular}

*The risk in the intervention group (and its 95\% confidence interval) is based on the assumed risk in the comparison group and the relative effect of the intervention (and its 95\% CI).

CI: Confidence interval; RR: Risk ratio; MD: Mean difference

\section{GRADE Working Group grades of evidence}

High certainty: We are very confident that the true effect lies close to that of the estimate of the effect Moderate certainty: We are moderately confident in the effect estimate: The true effect is likely to be close to the estimate of the effect, but there is a possibility that it is substantially different

Low certainty: Our confidence in the effect estimate is limited: The true effect may be substantially different from the estimate of the effect

Very low certainty: We have very little confidence in the effect estimate: The true effect is likely to be substantially different from the estimate of effect

Explanation

a. We downgraded by one for the high risk of bias for allocation concealment because the authors reported that allocation to the treatment group was not concealed. [29]

b. We downgraded the evidence by one for imprecision; this was one small study [28]

c. We downgraded for this outcome by two for serious imprecision. This was a small trial [28] 
Appendix 4: Summary of findings table showing BCG revaccination compared to Placebo for preventing tuberculosis

Patient or population: Healthy participants

Setting: Community

Intervention: $\mathrm{BCG}$ revaccination

Comparison: Placebo

\begin{tabular}{|c|c|c|c|c|c|c|}
\hline \multirow[t]{2}{*}{ Outcomes } & \multicolumn{2}{|c|}{$\begin{array}{c}\text { Anticipated absolute } \\
\text { effects* }^{*} \\
(95 \% \mathrm{CI})\end{array}$} & \multirow[t]{2}{*}{$\begin{array}{l}\text { Relative } \\
\text { effect } \\
(95 \% \mathrm{CI})\end{array}$} & \multirow[t]{2}{*}{$\begin{array}{c}\text { № of } \\
\text { participants } \\
\text { (studies) }\end{array}$} & \multirow[t]{2}{*}{$\begin{array}{l}\text { Certainty of } \\
\text { the evidence } \\
\text { (GRADE) }\end{array}$} & \multirow[t]{2}{*}{ Comments } \\
\hline & $\begin{array}{l}\text { Risk with } \\
\text { Placebo }\end{array}$ & $\begin{array}{c}\text { Risk with } \\
\text { BCG } \\
\text { revaccination }\end{array}$ & & & & \\
\hline $\begin{array}{l}\text { TB/HIV } \\
\text { Co-infection }\end{array}$ & 0 per 1,000 & $\begin{array}{c}1 \text { per } 1,000 \\
(0 \text { to } 5)\end{array}$ & $\begin{array}{l}\text { RR } 13.91 \\
(1.83 \text { to } \\
105.78)\end{array}$ & $\begin{array}{c}46764 \\
\text { (1 study) }\end{array}$ & $\begin{array}{c}\oplus \oplus \bigcirc \bigcirc \\
\text { LOW, [24],a, - }\end{array}$ & \\
\hline Latent TB & 149 per 1,000 & $\begin{array}{c}124 \text { per } 1,000 \\
(83 \text { to } 182)\end{array}$ & $\begin{array}{l}\text { RR } 0.85 \\
(0.62 \text { to } \\
1.17)\end{array}$ & $\begin{array}{c}659 \\
\text { (1 study) }\end{array}$ & $\begin{array}{c}\oplus \oplus \oplus \bigcirc \\
\text { MODERATE, } \\
{[26], c_{-}}\end{array}$ & \\
\hline $\begin{array}{l}\text { Active TB } \\
\text { (Pulmonary TB) }\end{array}$ & 1 per 1,000 & $\begin{array}{c}1 \text { per } 1,000 \\
(1 \text { to } 3)\end{array}$ & $\begin{array}{l}\text { RR } 1.74 \\
(1.00 \text { to } \\
3.01)\end{array}$ & $\begin{array}{c}46764 \\
\text { (1 study) }\end{array}$ & $\begin{array}{c}\oplus \oplus \oplus \bigcirc \\
\text { MODERATE, } \\
{[24], \mathrm{b}}\end{array}$ & \\
\hline $\begin{array}{l}\text { Active TB } \\
\text { (Non- } \\
\text { pulmonary TB) }\end{array}$ & 0 per 1,000 & $\begin{array}{c}0 \text { per } 1,000 \\
(0 \text { to } 1)\end{array}$ & $\begin{array}{l}\text { RR } 0.55 \\
(0.19 \text { to } \\
1.65)\end{array}$ & $\begin{array}{c}46764 \\
\text { (1 study) }\end{array}$ & $\begin{array}{c}\oplus \oplus \oplus \bigcirc \\
\text { MODERATE, } \\
{[22], \mathrm{b}}\end{array}$ & \\
\hline $\begin{array}{l}\text { Cellular } \\
\text { immune } \\
\text { responses } \\
\text { (QFT } \\
\text { conversion) }\end{array}$ & 202 per 1,000 & $\begin{array}{c}170 \text { per } 1,000 \\
(125 \text { to } 233)\end{array}$ & $\begin{array}{l}\text { RR } 0.84 \\
(0.62 \text { to } \\
1.15)\end{array}$ & $\begin{array}{c}695 \\
\text { (2 studies) }\end{array}$ & $\begin{array}{c}\oplus \oplus \bigcirc \bigcirc \\
L O W,[26,30], c\end{array}$ & \\
\hline $\begin{array}{l}\text { All-cause } \\
\text { mortality }\end{array}$ & 3 per 1,000 & $\begin{array}{l}1 \text { per } 1,000 \\
(0 \text { to } 24)\end{array}$ & $\begin{array}{l}\text { RR } 0.33 \\
(0.01 \text { to } \\
8.13)\end{array}$ & $\begin{array}{c}659 \\
\text { (1 study) }\end{array}$ & $\begin{array}{c}\oplus \bigoplus \bigcirc \bigcirc \\
L O W,[26], \mathrm{d}\end{array}$ & \\
\hline $\begin{array}{l}\text { Adverse events: } \\
\text { - Any Adverse } \\
\text { events }\end{array}$ & 323 per 1,000 & $\begin{array}{l}855 \text { per } 1,000 \\
(542 \text { to } 1,000)\end{array}$ & $\begin{array}{c}\text { RR } 2.65 \\
(1.68 \text { to } \\
4.17)\end{array}$ & $\begin{array}{c}695 \\
\text { (2 studies) }\end{array}$ & $\begin{array}{c}\oplus \oplus \bigcirc \bigcirc \\
\text { LOW, }[26,30], c, d\end{array}$ & \\
\hline $\begin{array}{l}\text { Adverse events: } \\
\text { - Moderate AE }\end{array}$ & 64 per 1,000 & $\begin{array}{l}54 \text { per } 1,000 \\
(29 \text { to } 100)\end{array}$ & $\begin{array}{l}\text { RR } 0.85 \\
(0.46 \text { to } \\
1.57)\end{array}$ & $\begin{array}{c}659 \\
\text { (1 study) }\end{array}$ & $\begin{array}{c}\oplus \oplus \bigcirc \bigcirc \\
L O W,[26], \mathrm{d}\end{array}$ & \\
\hline $\begin{array}{l}\text { Adverse events } \\
\text { - } \\
\text { Severe AE }\end{array}$ & 6 per 1,000 & $\begin{array}{c}3 \text { per } 1,000 \\
(0 \text { to } 33)\end{array}$ & $\begin{array}{l}\text { RR } 0.50 \\
(0.05 \text { to } \\
5.47)\end{array}$ & $\begin{array}{c}659 \\
\text { (1 study) }\end{array}$ & $\begin{array}{c}\oplus \oplus \bigcirc \bigcirc \\
\text { LOW, [26],d }\end{array}$ & \\
\hline
\end{tabular}


Appendix 4: Summary of findings table showing BCG revaccination compared to Placebo for preventing tuberculosis

Patient or population: Healthy participants

Setting: Community

Intervention: $\mathrm{BCG}$ revaccination

Comparison: Placebo

\begin{tabular}{|c|c|c|c|c|c|c|}
\hline \multirow[t]{2}{*}{ Outcomes } & \multicolumn{2}{|c|}{$\begin{array}{c}\text { Anticipated absolute } \\
\text { effects* }^{*} \\
(95 \% \mathrm{CI})\end{array}$} & \multirow[t]{2}{*}{$\begin{array}{c}\text { Relative } \\
\text { effect } \\
(95 \% \mathrm{CI})\end{array}$} & \multirow[t]{2}{*}{$\begin{array}{c}\text { № of } \\
\text { participants } \\
\text { (studies) }\end{array}$} & \multirow[t]{2}{*}{$\begin{array}{c}\text { Certainty of } \\
\text { the evidence } \\
\text { (GRADE) }\end{array}$} & \multirow[t]{2}{*}{ Comments } \\
\hline & $\begin{array}{c}\text { Risk with } \\
\text { Placebo }\end{array}$ & $\begin{array}{c}\text { Risk with } \\
\text { BCG } \\
\text { revaccination }\end{array}$ & & & & \\
\hline
\end{tabular}

*The risk in the intervention group (and its $95 \%$ confidence interval) is based on the assumed risk in the comparison group and the relative effect of the intervention (and its 95\% CI).

CI: Confidence interval; OR: Odds ratio; RR: Risk ratio

\section{GRADE Working Group grades of evidence}

High certainty: We are very confident that the true effect lies close to that of the estimate of the effect Moderate certainty: We are moderately confident in the effect estimate: The true effect is likely to be close to the estimate of the effect, but there is a possibility that it is substantially different

Low certainty: Our confidence in the effect estimate is limited: The true effect may be substantially different from the estimate of the effect

Very low certainty: We have very little confidence in the effect estimate: The true effect is likely to be substantially different from the estimate of effect

a. We downgraded by two for very serious imprecision due to its very wide confidence interval, although this was a large trial. [24]

b. We downgraded by one for this outcome for serious imprecision. [24]

c. We downgraded for this outcome by two for serious imprecision and high risk of bias. [26,30]

d. We downgrade by two for this outcome for serious imprecision and substantial heterogeneity. [26, 30] 